\title{
PENGARUH PERBANDINGAN MASSA ECENG GONDOK DAN TEMPURUNG KELAPA SERTA KADAR PEREKAT TAPIOKA TERHADAP KARAKTERISTIK BRIKET
}

\author{
Iriany, Meliza*, Firman Abednego S. Sibarani, Irvan \\ Departemen Teknik Kimia, Fakultas Teknik, Universitas Sumatera Utara \\ Jl. Almamater Kampus USU, Medan 20155, Indonesia \\ *Email: meliza238@yahoo.com
}

\begin{abstract}
Abstrak
Tujuan penelitian ini adalah untuk mengetahui karakteristik dari briket yang dihasilkan, meliputi kadar abu, kadar air, kadar zat volatil, nilai kalor, kerapatan, laju pembakaran, kuat tekan, serta untuk mengetahui perbandingan yang sesuai dari campuran eceng gondok dan tempurung kelapa dengan variasi kadar perekat tapioka. Perbandingan massa antara eceng gondok dan tempurung kelapa pada penelitian ini yaitu : 1:1, 1:2, 1:3, 1:4 dengan variasi kadar perekat tapioka sebesar 5\%, 10\%, dan 15\% dari berat bahan baku. Dari hasil penelitian ini diperoleh bahwa komposisi briket yang ideal diperoleh pada campuran eceng gondok dan tempurung kelapa pada perbandingan 1:4 dengan kadar perekat tapioka 10\% yaitu dengan nilai kalor $6.879,596 \mathrm{kal} / \mathrm{g}$, kadar abu 9,718\%, kadar air 1,374\%, kadar zat volatil 14,814\%, nilai kerapatan $0,983 \mathrm{~g} / \mathrm{cm}^{3}$, laju pembakaran $3,021 \times 10^{-3} \mathrm{~g} /$ detik dan kuat tekan $18,400 \mathrm{~g} / \mathrm{cm}^{2}$.
\end{abstract}

Kata kunci: briket, eceng gondok, tempurung kelapa, tapioka

\begin{abstract}
The purpose of this research is to know the characteristics of briquettes including ash content, moisture content, volatile matter content, heating value, density, burning rate, tensile strength and to know the proper ratio of water hyacinth and coconut shell mixture under tapioca gluten variation. The ratios of water hyacinth and coconut shell in this research were 1:1, 1:2, 1:3, 1:4 with variation of tapioca gluten $5 \%, 10 \%$, and $15 \%$ of the raw materials. From this research, the ideal composition of briquette is obtain in a mixture of water hyacinth and coconut shell at a ratio of 1:4 with tapioca gluten 10\%, ash content $9.718 \%$, moisture content $1.374 \%$, volatile matter content $14.814 \%$, heating value $6,879.596 \mathrm{cal} / \mathrm{g}$, density $0.983 \mathrm{~g} / \mathrm{cm}^{3}$, burning rate $3.021 \times 10^{-3} \mathrm{~g} /$ second and tensile strength $18.400 \mathrm{~g} / \mathrm{cm}^{2}$.
\end{abstract}

Keywords: briquette, water hyacinth, coconut shell, tapioca

\section{Pendahuluan}

Seiring semakin meningkatnya pertumbuhan jumlah penduduk maka kebutuhan energi semakin meningkat setiap tahunnya. Salah satu sumber energi utama yang dikonsumsi oleh manusia adalah sumber energi yang berasal dari fosil, yang lambat laun akan habis karena tidak dapat diperbaharui. Oleh karena itu, diperlukan suatu sumber energi alternatif untuk mengurangi ketergantungan terhadap bahan bakar fosil. Usaha dalam mencari pengganti sumber energi fosil harus didasarkan pada bahan bakunya mudah diperoleh dan dapat diperbaharui. Salah satunya adalah energi yang berasal dari biomassa.

Biomassa dapat diperoleh dari limbah pertanian, limbah rumah tangga, dan limbah industri. Agar dimanfaatkan sebagai bahan bakar maka limbah tersebut dapat diolah menjadi bahan bakar padat dalam bentuk briket. Salah satu biomassa yang dapat dijadikan briket adalah eceng gondok dan tempurung kelapa. Pemilihan bahan ini dilakukan karena pemanfaatan akan limbah eceng gondok dan tempurung kelapa berpotensi meningkatkan nilai ekonomi dari limbah tersebut.

\section{Teori}

Briket merupakan suatu padatan yang dihasilkan melalui proses pemampatan dan pemberian tekanan, apabila dibakar akan menghasilkan sedikit asap. Briket diolah dengan sistem pengepresan dan menggunakan bahan perekat, sehingga berbentuk briket yang dapat digunakan untuk keperluan sehari-hari [2]. Adapun keuntungan dari bentuk briket yang dicetak yaitu, ukuran dapat disesuaikan dengan kebutuhan, porositasnya dapat diatur untuk memudahkan pembakaran, serta mudah dibakar sebagai bahan bakar. Pengolahan menjadi briket bertujuan untuk meningkatkan karakteristik bahan baku serta nilai kalor dari biomassa [4].

Faktor-faktor yang mempengaruhi sifat briket arang adalah kerapatan bahan bakar atau kerapatan serbuk arang, kehalusan serbuk, suhu karbonisasi, dan tekanan pada saat dilakukan pencetakan. Selain itu, pencampuran formula dengan briket juga mempengaruhi sifat briket [5].

Eceng Gondok (Eichornia crassipes) merupakan tumbuhan air yang tumbuh di rawarawa, danau, waduk, dan sungai yang alirannya tenang. Pertumbuhan eceng gondok yang sangat 
cepat dapat menimbulkan berbagai masalah, antara lain mempercepat pendangkalan sungai atau danau, menurunkan produksi ikan, mempersulit saluran irigasi, serta menyebabkan penguapan air 3 hingga 7 kali lebih besar daripada penguapan air di perairan terbuka. Eceng gondok memiliki kandungan air yang sangat besar yaitu hingga 90\% dari berat tanaman sebenarnya [8].

Tempurung kelapa merupakan lapisan keras yang terletak di bagian dalam kelapa setelah sabut. Tempurung kelapa memiliki lapisan keras dengan ketebalan antara $3 \mathrm{~mm}$ sampai dengan $5 \mathrm{~mm}$. Banyaknya kandungan silikat $\left(\mathrm{SiO}_{2}\right)$ yang terdapat pada tempurung menyebabkan sifatnya menjadi keras. Dari berat total buah kelapa, 15 sampai $19 \%$ diantaranya merupakan berat tempurung [11].

Tanaman enceng gondok dan tempurung kelapa memiliki kandungan selulosa dan senyawa organik sehingga berpotensi memberikan nilai kalor yang cukup baik. Dengan demikian briket dari enceng gondok dan tempurung kelapa ini dapat dimanfaatkan sebagai bahan bakar alternatif yang berpotensi memberikan dampak yang sangat baik bagi lingkungan serta bernilai ekonomis.

Pada pembuatan briket, biomassa terlebih dahulu dikarbonisasi untuk dijadikan arang. Proses karbonisasi atau pengarangan adalah proses mengubah bahan baku menjadi karbon berwarna hitam melalui pembakaran dalam ruang tertutup dengan udara yang terbatas atau seminimal mungkin. Proses karbonisasi atau pengarangan bertujuan untuk menaikkan nilai kalor biomassa serta menghasilkan pembakaran yang bersih dengan sedikit asap. Hasil karbonisasi berupa arang yang tersusun atas karbon berwarna hitam [7].

Untuk merekatkan partikel-partikel zat dalam bahan baku pada proses pembuatan briket, diperlukan zat perekat sehingga dihasilkan briket yang mengikat. Dengan adanya penggunaan bahan perekat maka ikatan antar partikel akan semakin kuat, butir-butir arang akan saling menyatu, susunan partikel juga akan semakin baik sehingga dalam proses pengempaan briket akan semakin baik. Syarat utama dari bahan perekat adalah harus dapat ikut terbakar dan dapat menambah nilai kalor [10].

Salah satu jenis perekat yang sering digunakan dalam pembuatan briket adalah tapioka. Bahan perekat yang terbuat dari tepung tapioka memiliki beberapa sifat diantaranya :

1. Daya serap terhadap air.

2. Mempunyai kekuatan perekatan yang baik.

3. Mudah didapat dan tidak mengganggu kesehatan.

4. Mudah dicampur dengan bahan baku lainnya, dalam hal ini tepung arang [5].

\section{Metodologi Penelitian}

Penelitian ini menggunakan bahan baku eceng gondok dan tempurung kelapa dengan menggunakan perekat tapioka untuk pembuatan briket. Dalam penelitian ini digunakan peralatan seperti: neraca, hammer mill, ayakan mesh 60, screening dengan vibrator, furnace, oven, desikator dan tensile test.

Adapun variabel pada penelitian ini yaitu :

a. Variabel tetap, yaitu :

- Ukuran partikel arang dengan menggunakan ayakan 60 mesh.

- Berat eceng gondok 20 gram untuk setiap pencetakan briket.

- Suhu karbonisasi eceng gondok dan tempurung kelapa yaitu $400{ }^{\circ} \mathrm{C}$.

- Tekanan kempa briket 1 ton $/ \mathrm{cm}^{2}$.

- Perekat tapioka dengan perbandingan massa tapioka dan air yaitu 1:4

b.Variabel berubah, yaitu :

Perbandingan antara eceng gondok dan tempurung kelapa serta persentase perekat tapioka dari berat total bahan baku ditunjukkan seperti pada Tabel 1 .

Tabel 1. Variasi Kadar Perekat Tapioka dengan Perbanding Bahan Baku Eceng Gondok dan Tempurung Kelapa

\begin{tabular}{|c|c|}
\hline $\begin{array}{c}\text { Kadar Perekat } \\
\text { Tapioka } \\
(\%)\end{array}$ & $\begin{array}{c}\text { Perbandingan } \\
\text { Eceng Gondok : } \\
\text { Tempurung Kelapa }\end{array}$ \\
\hline & $1: 1$ \\
5 & $1: 2$ \\
& $1: 3$ \\
$1: 4$ \\
\hline & $1: 1$ \\
& $1: 2$ \\
& $1: 3$ \\
& $1: 4$ \\
\hline & $1: 1$ \\
15 & $1: 2$ \\
& $1: 3$ \\
& $1: 4$ \\
\hline
\end{tabular}

Prosedur Pembuatan Arang

- Bahan baku berupa eceng gondok dan tempurung kelapa dicacah kecil-kecil $\pm 1 \mathrm{~cm}$.

- Eceng gondok dikarbonisasi di dalam furnace dengan suhu $400{ }^{\circ} \mathrm{C}$ selama 15 menit sedangkan tempurung kelapa dikarbonisasi di dalam furnace pada suhu $400{ }^{\circ} \mathrm{C}$ selama 1 jam untuk dijadikan arang.

Prosedur Pembuatan Briket

- Arang hasil pengarangan dari eceng gondok dan tempurung kelapa digiling dengan menggunakan hammer mill untuk dijadikan serbuk arang. 
- Serbuk arang disaring dengan alat pengayak ukuran 60 mesh untuk mendapatkan material yang seragam.

- Komposisi bahan baku divariasikan sesuai dengan yang telah ditentukan. Variasi perbandingan eceng gondok dan tempurung kelapa dalam penelitian ini adalah $1: 1 ; 1: 2 ; 1: 3$; 1:4 dengan berat eceng gondok 20 gram (dalam penelitian ini berat briket yang dicetak 35 gram untuk setiap penelitian).

- Perekat dari tepung tapioka dibuat dengan cara mencampurkan tepung tapioka dengan air kemudian dipanaskan pada suhu $\pm 70{ }^{\circ} \mathrm{C}$ hingga menjadi adonan seperti bubur. Perbandingan antara tapioka dan air yaitu 1:4.

- Adonan tepung tapioka dengan kadar 5\%, 10\%, dan $15 \%$ sebagai perekat dicampurkan dengan serbuk arang dari hasil pengayakan sehingga menghasilkan adonan yang lengket.

- Adonan diaduk hingga bahan tercampur rata.

- Adonan briket dicetak menggunakan alat pencetak briket kemudian ditekan dengan kekuatan tekan 1 ton $/ \mathrm{cm}^{2}$.

- Briket yang sudah dicetak kemudian dikeringkan di dalam oven pada suhu $105{ }^{\circ} \mathrm{C}$ selama satu jam agar diperoleh briket dengan kadar air yang rendah.

\section{Hasil dan Pembahasan \\ Kadar Abu}

Pengujian kadar abu dilakukan berdasarkan SNI 06-3730-1995 [9]. Penentuan kadar abu bertujuan untuk mengetahui bagian yang tidak terbakar yang sudah tidak memiliki unsur karbon lagi setelah briket dibakar. Kadar abu briket pada berbagai perbandingan eceng gondok dan tempurung kelapa serta kadar perekat dapat dilihat pada Gambar 1.

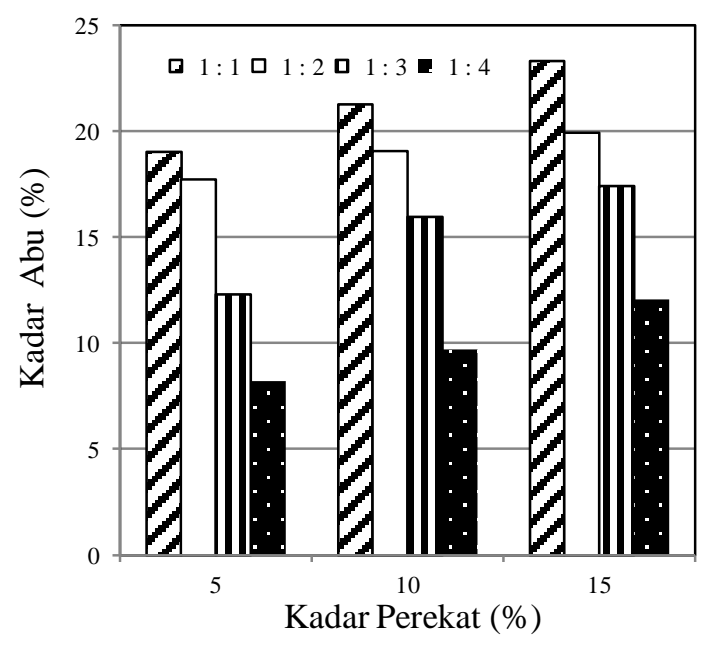

Gambar 1. Pengaruh Perbandingan Eceng Gondok dan Tempurung Kelapa Serta Kadar Perekat Tapioka Terhadap Kadar Abu
Berdasarkan Gambar 1 dapat dilihat bahwa kadar abu yang dihasilkan dari penelitan ini adalah 8,211 - 23,326\%. Kadar abu tertinggi diperoleh pada briket dengan perbandingan eceng gondok dan tempurung kelapa 1:1 menggunakan perekat tapioka 15\%. Kadar abu terendah diperoleh pada briket perbandingan 1:4 dengan perekat tapioka $5 \%$.

Kadar abu akan semakin meningkat dengan semakin sedikitnya tempurung kelapa dan semakin banyaknya kadar perekat tapioka. Hal ini disebabkan kandungan abu pada eceng gondok lebih tinggi yaitu $12 \%$ [1] dan tempurung kelapa memiliki kandungan abu 0,60\% [10]. Selain itu, semakin tingginya kadar perekat tapioka dapat menyebabkan kenaikan kadar abu karena dipengaruhi oleh kandungan bahan anorganik pada tepung tapioka.

Meskipun bahan perekat memberikan peningkatan kadar abu pada briket, namun bahan perekat harus tetap digunakan. Briket yang tidak menggunakan bahan perekat memiliki kerapatan yang rendah sehingga briket akan mudah hancur serta sukar untuk dijadikan sebagai bahan bakar. Kadar abu yang tinggi akan menimbulkan kerak serta dapat menurunkan kualitas briket yang dihasilkan [9].

Nilai kadar abu yang diperoleh dari briket pada perbandingan eceng gondok dan tempurung kelapa 1:4 dengan perekat tapioka 5\% dan 10\% telah memenuhi SNI yaitu kadar abu maksimal $10 \%$, standar Inggris $8-10 \%$ dan Amerika maksimal $16 \%$, sedangkan untuk standar briket buatan Jepang kadar abu yang dihasilkan belum terpenuhi yaitu maksimal 7\% [3]. Briket pada perbandingan 1:3 dengan perekat tapioka 5\% dan $10 \%$ hanya memenuhi standar Amerika. Briket dengan perbandingan lainnya tidak memenuhi standar mutu briket keempat negara tersebut.

\section{Kadar Air}

Pengujian kadar air dilakukan berdasarkan SNI 06-3730-1995 [9]. Kadar air pada briket merupakan jumlah air yang masih terdapat di dalam briket setelah dilakukan pemanasan. Kadar air sangat mempengaruhi kualitas briket yang dihasilkan. Jika kadar air briket semakin tinggi maka daya pembakarannya semakin rendah, dan sebaliknya. Hal ini disebabkan panas yang diberikan kepada briket digunakan terlebih dahulu untuk menguapkan air yang terdapat di dalam briket. Akibatnya briket menjadi susah untuk dinyalakan. Nilai kadar air pada briket dipengaruhi oleh jenis bahan baku, jenis perekat, dan metode pengujian yang dilakukan. Kadar air briket pada berbagai perbandingan eceng gondok dan tempurung kelapa serta kadar perekat dapat dilihat pada Gambar 2. 


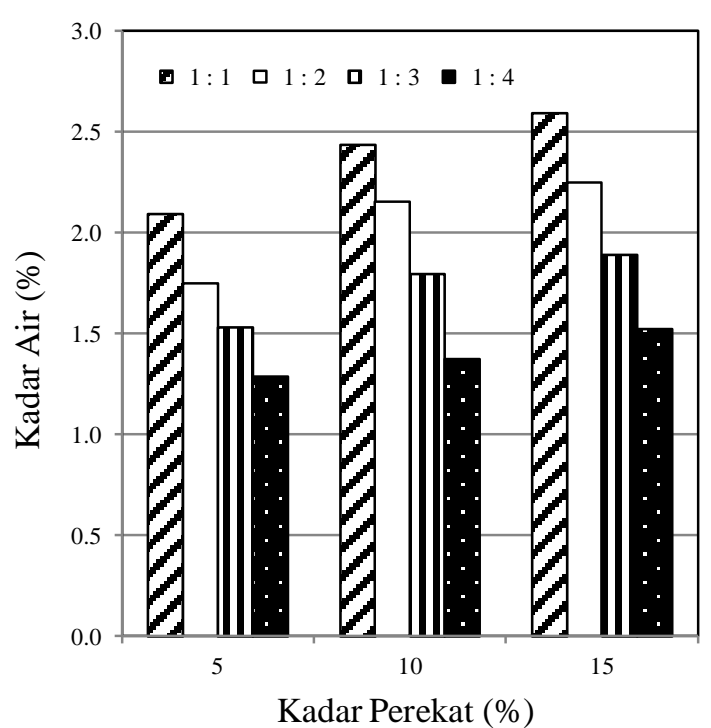

Gambar 2. Pengaruh Perbandingan Eceng Gondok dan Tempurung Kelapa Serta Kadar Perekat Tapioka Terhadap Kadar Air

Berdasarkan Gambar 2 dapat dilihat bahwa kadar air yang terkandung dalam briket adalah 1,289 - 2,594\%. Kadar air tertinggi terdapat pada sampel dengan perbandingan eceng gondok dan tempurung kelapa 1:1 dengan kadar perekat $15 \%$. Kadar air terendah terdapat pada perbandingan 1:4 dengan kadar perekat $5 \%$.

Semakin sedikit tempurung kelapa dan semakin tinggi kadar perekat tapioka yang terdapat di dalam briket maka kadar air semakin tinggi. Hal ini disebabkan karena kandungan kadar air dalam eceng gondok lebih besar yaitu 90\% di dalam eceng gondok segar [8], sedangkan tempurung kelapa memilki kadar air 8\% [10]. Kadar perekat tapioka yang digunakan juga mempengaruhi kadar air karena air yang terkandung dalam perekat akan masuk dan terikat dalam pori-pori arang. Briket yang mengandung kadar air yang tinggi akan mudah ditumbuhi oleh jamur dan sulit untuk dinyalakan [9].

Secara keseluruhan, briket yang dihasilkan telah sesuai dengan SNI, standar mutu Jepang, Inggris dan Amerika. Kadar air briket menurut SNI dan standar mutu Jepang yaitu maksimal $8 \%$, standar mutu Amerika maksimal 6\% dan standar mutu Inggris 3 - 4\% [3].

\section{Kadar Zat Volatil}

Pengujian kadar zat volatil dilakukan berdasarkan SNI 06-3730-1995 [9]. Zat volatil adalah zat yang dapat menguap sebagai hasil dekomposisi senyawa-senyawa yang masih terdapat di dalam briket selain air dan kadar abu. Tinggi rendahnya kadar zat volatil pada briket yang dihasilkan dipengaruhi oleh komposisi campuran bahan baku. Kadar zat volatil briket pada berbagai perbandingan eceng gondok dan tempurung kelapa serta kadar perekat tapioka dapat dilihat pada Gambar 3.

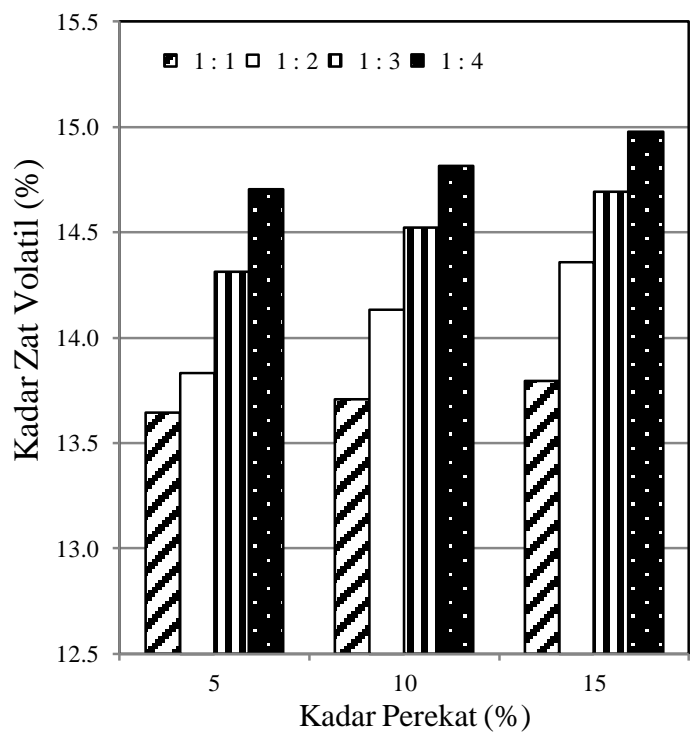

Gambar 3. Pengaruh Perbandingan Eceng Gondok dan Tempurung Kelapa Serta Kadar Perekat Tapioka Terhadap Kadar Zat Volatil

Gambar 3 menunjukkan kadar zat volatil yang diperoleh pada penelitian ini berkisar antara $13,645-14,978 \%$. Kadar zat volatil terendah diperoleh pada briket dengan perbandingan eceng gondok dan tempurung kelapa 1:1 menggunakan perekat tapioka 5\%. Kadar zat volatil tertinggi diperoleh pada briket dengan perbandingan 1:4 menggunakan perekat tapioka $15 \%$.

Kadar zat volatil semakin meningkat seiring dengan semakin banyaknya tempurung kelapa dan kadar perekat tapioka di dalam briket. Hal ini disebabkan adanya kandungan zat-zat menguap seperti $\mathrm{CO}, \mathrm{CO}_{2}, \mathrm{H}_{2}, \mathrm{CH}_{4}$ dan $\mathrm{H}_{2} \mathrm{O}$ yang terdapat pada arang tempurung kelapa yang digunakan ikut menguap. Kadar perekat tapioka yang digunakan juga mempengaruhi kadar zat volatil. Pada saat pemanasan briket arang, perekat yang digunakan ikut menguap sehingga kadar zat volatil yang dihasilkan menjadi lebih besar dengan bertambahnya kadar perekat. Kandungan kadar zat volatil yang tinggi di dalam briket akan menyebabkan asap yang lebih banyak pada saat pembakaran briket [9].

Kadar zat volatil yang diperoleh pada penelitian ini telah memenuhi SNI yaitu maksimal $15 \%$, standar Inggris maksimal $16,4 \%$, tetapi belum memenuhi standar briket buatan Amerika yaitu 19 - 28\% dan standar Jepang yang berkisar $15-30 \%$ [5]. 


\section{Nilai Kalor}

Pengujian nilai kalor dilakukan berdasarkan ISO 9001-2008. Nilai kalor dalam pembuatan briket perlu diketahui untuk memperoleh nilai panas pembakaran yang dapat dihasilkan oleh briket sebagai bahan bakar. Semakin tinggi nilai kalor yang dihasilkan oleh briket, maka akan semakin baik kualitasnya. Nilai kalor briket pada berbagai perbandingan eceng gondok dan tempurung kelapa serta kadar perekat dapat dilihat pada Gambar 4.

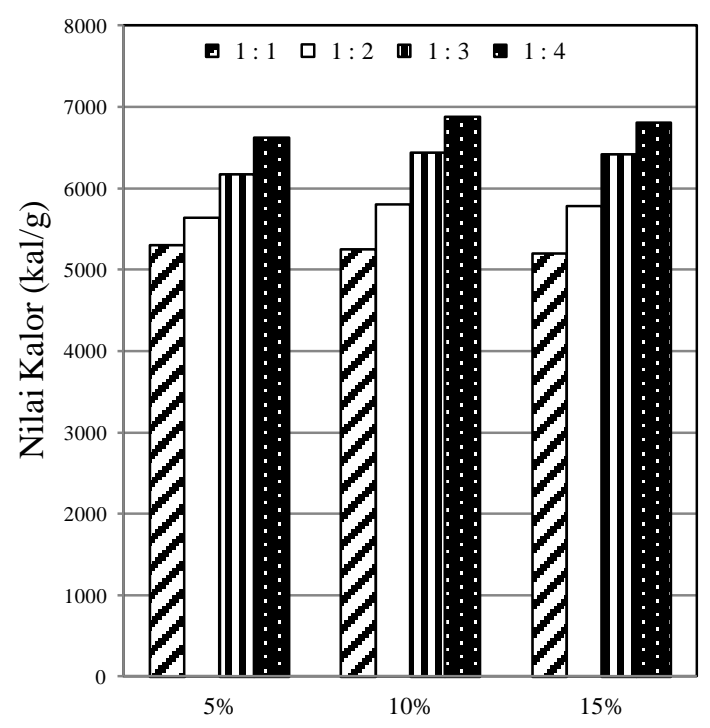

Kadar Perekat

Gambar 4. Pengaruh Perbandingan Eceng Gondok dan Tempurung Kelapa Serta Kadar Perekat Tapioka Terhadap Nilai Kalor

Gambar 4 menunjukkan bahwa nilai kalor yang dihasilkan berkisar antara 5.202,578 $6.879,596 \mathrm{kal} / \mathrm{g}$. Nilai kalor tertinggi dihasilkan pada briket dengan perbandingan eceng gondok dan tempurung kelapa 1:4 dengan perekat $10 \%$. Nilai kalor terendah dihasilkan pada briket dengan perbandingan eceng gondok dan tempurung kelapa 1:1 dengan perekat $15 \%$.

Dari hasil penelitian ini dapat disimpulkan bahwa semakin banyak jumlah tempurung kelapa yang ditambahkan di dalam briket maka semakin tinggi nilai kalor yang dihasilkan. Hal ini disebabkan tempurung kelapa memiliki nilai kalor yang lebih tinggi yaitu 7.345,914 kal/g [6], sedangkan eceng gondok memiliki nilai kalor $3.207 \mathrm{kal} / \mathrm{g}$ [8]. Sehingga dengan semakin banyaknya tempurung kelapa yang ditambahkan maka nilai kalor akan semakin meningkat. Peningkatan kadar perekat juga dapat mempengaruhi kenaikan nilai kalor, namun jika kadar perekat yang ditambahkan semakin tinggi dapat meningkatkan kadar air dan kadar abu briket.
Berdasarkan hasil pengujian nilai kalor dapat dilihat bahwa briket pada perbandingan 1:1 dengan perekat tapioka 5\%,10\%, dan $15 \%$ tidak sesuai SNI yaitu minimal $5.600 \mathrm{kal} / \mathrm{g}$, sedangkan untuk briket dengan perbandingan lainnya telah memenuhi SNI. Untuk standar mutu Jepang (5.000 - $6.000 \mathrm{kal} / \mathrm{g}$ ) dan Amerika (4.000 - 6.500 $\mathrm{kal} / \mathrm{g}$ ) semua briket yang dihasilkan telah memenuhi standar. Untuk briket dengan perbandingan eceng gondok dan tempurung kelapa 1:1 dan 1:2 dengan perekat $5 \%$ dan $15 \%$, perbandingan 1:1 dengan perekat $10 \%$ belum memenuhi standar Inggris yaitu minimal 5.870 $\mathrm{kal} / \mathrm{g}$. Untuk briket dengan perbandingan lainnya telah memenuhi standar Inggris [3].

\section{Kerapatan}

Kerapatan pada briket berkaitan dengan kekompakan briket dilihat dari bobot per satuan volume. Briket dengan kerapatan yang lebih tinggi akan lebih kompak dibanding briket dengan kerapatan yang lebih rendah. Kerapatan pada briket dapat menentukan nilai bakar dari briket tersebut. Nilai kerapatan pada berbagai perbandingan eceng gondok dan tempurung kelapa serta kadar perekat dapat dilihat pada Gambar 5.

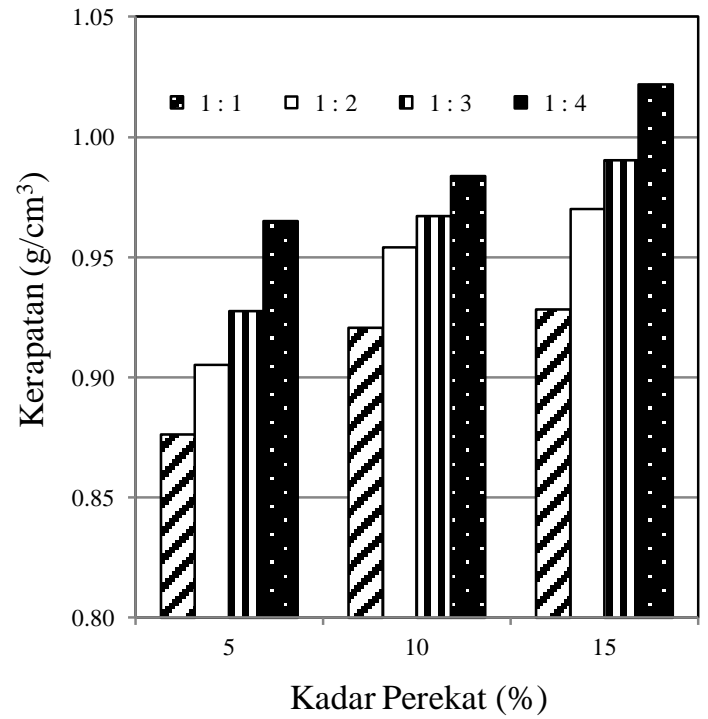

Gambar 5. Pengaruh Perbandingan Eceng Gondok dan Tempurung Kelapa Serta Kadar Perekat Tapioka Terhadap Kerapatan

Gambar 5 menunjukkan bahwa kerapatan briket yang dihasilkan adalah $0,876-1,021 \mathrm{~g} / \mathrm{cm}^{3}$. Nilai kerapatan yang tertinggi dihasilkan pada briket dengan perbandingan eceng gondok dan tempurung kelapa 1:4 dengan perekat tapioka $15 \%$, sedangkan kerapatan yang terendah dihasilkan oleh briket pada perbandingan 1:1 dengan perekat tapioka $5 \%$. 
Kerapatan dipengaruhi oleh keseragaman campuran arang dengan perekat. Nilai kerapatan yang tinggi akan mempengaruhi nilai kalor pada briket. Namun, nilai kerapatan yang terlalu tinggi akan mengakibatkan briket sulit terbakar, sedangkan briket yang mempunyai nilai kerapatan yang rendah akan lebih mudah terbakar karena rongga udaranya besar sehingga dapat dilalui oksigen dalam proses pembakaran. Briket dengan kerapatan yang rendah akan lebih cepat habis karena terlalu banyak rongga udara [3].

Peningkatan jumlah tempurung kelapa di dalam briket dapat memperluas ikatan antara partikel, sehingga dapat meningkatkan kerapatan briket karena ikatan antara serbuk arang menjadi lebih kompak [12]. Penambahan kadar perekat yang semakin tinggi akan menyebabkan briket mempunyai kerapatan yang semakin tinggi pula karena perekat akan masuk ke dalam pori-pori briket.

Dari hasil pengujian semua jenis briket yang diperoleh tidak memenuhi nilai kerapatan yang sesuai SNI $\left(0,5-0,6 \mathrm{~g} / \mathrm{cm}^{3}\right)$ dan standar mutu Inggris $\left(0,46-0,85 \mathrm{~g} / \mathrm{cm}^{3}\right)$. Briket pada perbandingan eceng gondok dan tempurung kelapa $1: 4$ dengan perekat $15 \%$ telah memenuhi standar mutu kerapatan briket buatan Jepang dan Amerika $\left(1,0-1,2 \mathrm{~g} / \mathrm{cm}^{3}\right)$ [3].

\section{Laju Pembakaran}

Laju pembakaran pada briket dapat dipengaruhi oleh komposisi campuran bahan baku, kerapatan, dan nilai kalor dari briket. Laju pembakaran briket pada berbagai perbandingan eceng gondok dan tempurung kelapa serta kadar perekat dapat dilihat pada Gambar 6.

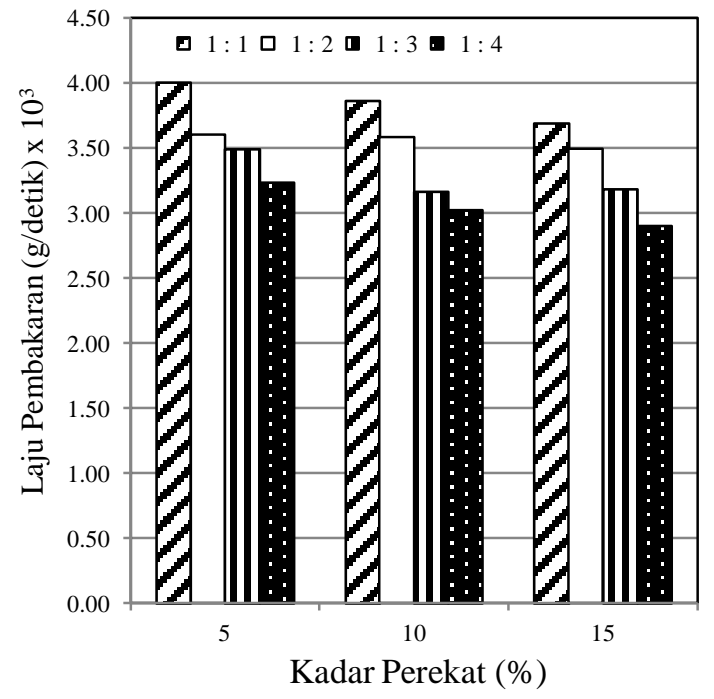

Gambar 6. Pengaruh Perbandingan Eceng Gondok dan Tempurung Kelapa Serta Kadar Perekat Tapioka Terhadap Laju Pembakaran
Gambar 6 menunjukkan bahwa laju pembakaran briket yang dihasilkan antara 2,900 $\times$ $10^{-3}-4,000 \times 10^{-3} \mathrm{~g} /$ detik. Nilai laju pembakaran tertinggi dihasilkan pada briket dengan perbandingan eceng gondok dan tempurung kelapa 1:1 dengan perekat 5\%. Nilai laju pembakaran terendah dihasilkan pada briket dengan perbandingan eceng gondok dan tempurung kelapa 1:4 dengan perekat $15 \%$.

Hasil penelitian ini menunjukkan bahwa semakin banyak tempurung kelapa dan kadar perekat tapioka di dalam briket maka akan semakin lama waktu pembakarannya sehingga laju pembakarannya semakin kecil. Hal ini disebabkan tempurung kelapa memiliki nilai kalor yang lebih tinggi dibandingkan eceng gondok. Semakin tinggi nilai kalor briket maka waktu pembakaran semakin lama. Selain itu, kadar perekat yang semakin tinggi meningkatkan nilai kerapatan. Semakin besar nilai kerapatan dari briket maka semakin lama waktu pembakarannya, sebab semakin rapat briket maka rongga udara semakin kecil sehingga semakin sukar dilalui oksigen pada saat proses pembakaran.

\section{Kuat Tekan}

Kuat tekan menunjukkan daya tahan briket terhadap tekanan sehingga mengakibatkan briket tersebut pecah atau hancur. Pada penelitian ini pengujian tekanan dilakukan pada sampel yang terbaik dari setiap kadar perekat tapioka yaitu briket eceng gondok dan tempurung kelapa pada perbandingan 1:4 dengan kadar perekat tapioka $5 \%$, 10\%, dan $15 \%$. Kuat tekan briket dengan perbandingan eceng gondok dan tempurung kelapa 1:4 serta kadar perekat dapat dilihat pada Gambar 7.

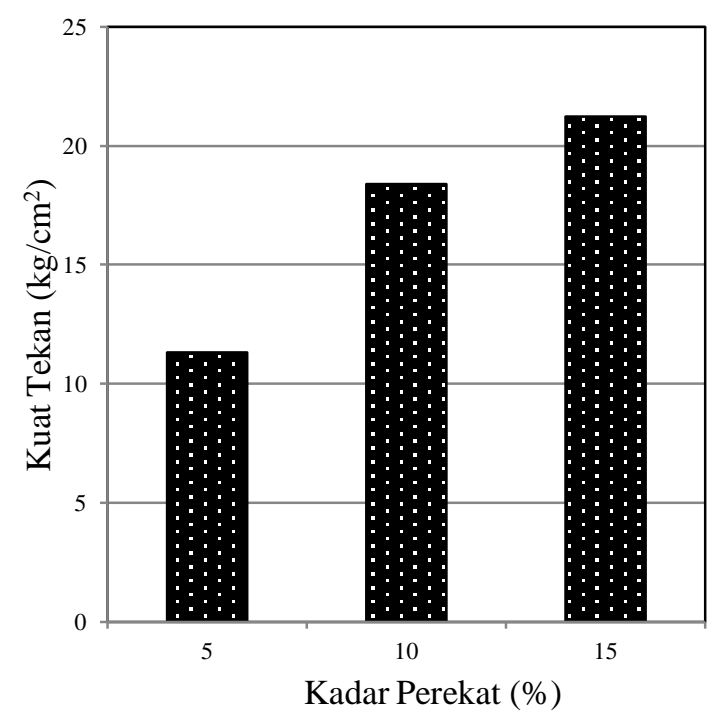

Gambar 7. Pengaruh Perbandingan Eceng Gondok dan Tempurung Kelapa 1:4 Serta Kadar Perekat Tapioka Terhadap Kuat Tekan 
Gambar 7 menunjukkan kuat tekan briket yang dihasilkan berkisar antara 11,323 - 21,231 $\mathrm{kg} / \mathrm{cm}^{2}$. Nilai kuat tekan tertinggi dihasilkan pada perbandingan eceng gondok dan tempurung kelapa 1:4 dengan kadar perekat tapioka 15\%, sedangkan nilai kuat tekan terendah dihasilkan dengan kadar perekat tapioka 5\%.

Semakin banyak kadar perekat tapioka yang ditambahkan maka akan semakin tinggi nilai kuat tekannya. Hal ini disebabkan kadar perekat yang lebih banyak di dalam briket dapat mengikat partikel arang dengan lebih baik sehingga partikel arang tersebut lebih menyatu dan kuat. Semakin besar nilai kuat tekan berarti daya tahan briket tersebut semakin baik.

Nilai kuat tekan briket pada perbandingan eceng gondok dan tempurung kelapa 1:4 dengan kadar perekat tapioka $10 \%$ dan $15 \%$ telah memenuhi standar mutu Inggris yaitu minimal $12,7 \mathrm{~kg} / \mathrm{cm}^{2}$, sedangkan briket dengan kadar perekat tapioka $5 \%$ tidak memenuhi standar mutu Inggris. Untuk nilai kuat tekan menurut SNI (minimal $50 \mathrm{~kg} / \mathrm{cm}^{2}$ ), standar Jepang (minimal 60 $\mathrm{kg} / \mathrm{cm}^{2}$ ) dan Amerika (minimal $62 \mathrm{~kg} / \mathrm{cm}^{2}$ ) semua briket yang dihasilkan pada penelitian ini tidak memenuhi standar [3].

\section{Kesimpulan}

Kesimpulan yang didapat dari hasil penelitian ini adalah:

1. Karakteristik briket campuran eceng gondok dan tempurung kelapa dengan perekat tapioka diperoleh kadar abu berkisar antara 8,211 23,326\%. Kadar air berkisar 1,289 - 2,594\%. Kadar zat volatil yaitu 13,645 - 14,978\%. Nilai kalor berkisar antara 5.202,578 $6.879,596 \mathrm{kal} / \mathrm{g}$. Nilai kerapatan berkisar antara $0,876-1,021 \mathrm{~g} / \mathrm{cm}^{3}$. Nilai laju pembakaran yaitu $2,900 \times 10^{-3}-4,000 \times 10^{-3}$ g/detik. Nilai Kuat tekan berkisar antara $11,323-21,231 \mathrm{~kg} / \mathrm{cm}^{2}$.

2. Perbandingan yang ideal terdapat pada perbandingan eceng gondok dan tempurung kelapa 1:4 menggunakan kadar perekat tapioka $10 \%$ yaitu kadar abu 9,718\%, kadar air $1,374 \%$, kadar zat volatil $14,814 \%$, nilai kalor $6.879,596 \mathrm{kal} / \mathrm{g}$, nilai kerapatan $0,983 \mathrm{~g} / \mathrm{cm}^{3}$, laju pembakaran $3,021 \times 10^{-3} \mathrm{~g} /$ detik, dan kuat tekan $18,400 \mathrm{~g} / \mathrm{cm}^{2}$.

\section{Daftar Pustaka}

[1] A. Rasyidi Fachry, dkk, Mencari Suhu Optimal Proses Karbonisasi dan Pengaruh Campuran Batubara Terhadap Kualitas Briket Eceng Gondok, Jurnal Teknik Kimia, Vol. 17, No. 2, April 2010, hal 55-67.

[2] Arni, Hosiana MD Labania, Anis Nismayanti, Studi Uji Karakteristik Fisis Briket Bioarang Sebagai Sumber Energi
Alternatif, Jurnal of Natural Science, Vol.3.1, Maret 2014, hal. 89-98.

[3] Dian Fatmawati, Priyo Heru Adiwibowo, Pembuatan Biobriket dari Campuran Enceng Gondok dan Tempurung Kelapa dengan Perekat Tetes Tebu, Jurnal JTM, Vol 3, No.2, 2014, hal. 315-322.

[4] Emerhi, E. A, Physical and Combustion Properties of Briquettes Produced From Sawdust of Three Hardwood Species and Different Organic Binders, Advances in Applied Science Research, Juni 2011, hal. 236-246.

[5] Erikson Sinurat, Studi Pemanfaatan Briket Kulit Jambu Mete dan Tongkol Jagung Sebagai Bahan Bakar Alternatif, Program Sarjana Fakultas Teknik Universitas Hasanuddin, Makasar, 2011.

[6] Esmar Budi, Tinjauan Proses Pembentukan dan Penggunaan Arang Tempurung Kelapa Sebagai Bahan Bakar, Jurnal Penelitian Sains, Volume 14, No. 4 B, Oktober 2011, hal. 25-29.

[7] Indah Suryani, M. Yusuf Permana U., M. Hatta Dahlan, Pembuatan Briket Arang Dari Campuran Buah Bintaro Dan Tempurung Kelapa Menggunakan Perekat Amilum, Jurnal Teknik Kimia, Vol. 18, No. 1, Januari 2012, hal. 24-29.

[8] Kharis Akbar Rafsanjani, Sarwono, Roni Dwi Noriyanti, Studi Pemanfaatan Potensi Biomassa dari Sampah Organik Sebagai Bahan Bakar Alternatif (Briket) dalam Mendukung Program Eco Campus Di ITS Surabaya, Jurnal Teknik POMITS, Vol.1, No.1, 2012, hal. 1-6.

[9] Maryono, Sudding, Rahmawati, Pembuatan dan Analisis Mutu Briket Arang Tempurung Kelapa Ditinjau Dari Kadar Kanji, Jurnal Chemical,Vol. 14, No.1, Juni 2013, hal.74-83.

[10] Nodali Ndraha. Uji Komposisi Bahan Pembuat Briket Bioarang Tempurung Kelapa dan Serbuk Kayu Terhadap Mutu Yang Dihasilkan, Program Sarjana Fakultas Pertanian USU, Medan, 2009, hal. 16-38.

[11] Santosa, Mislaini R, Swara Pratiwi Anugrah, Studi Variasi Komposisi Bahan Penyusun Briket Dari Kotoran Sapi Dan Limbah Pertanian, Jurnal Teknik Pertanian, Fakultas Teknologi Pertanian, Universitas Andalas, Padang, 2010, hal.20.

[12] Sarjono, Studi Eksperimental Perbandingan Nilai Kalor Briket Campuran Bioarang Sekam Padi Dan Tempurung Kelapa, Jurnal Simetris, No. 17, Juni-Desember 2013, hal. 11-18. 